\title{
REFINANSOWANIE DŁUGU POLSKICH GMIN
}

\section{WSTĘP}

Trudno byłoby nie zgodzić się z opinia, że gospodarka pozbawiona dostępu do instrumentów dłużnych jest fikcją ${ }^{1}$. Korzystanie z nich przez władze publiczne otwiera nowe możliwości, może jednak powodować poważne problemy, zarówno natury ekonomicznej, jak i społecznej.

Problematyka nadmiernego zadłużenia znajduje się w kręgu zainteresowań najwybitniejszych współczesnych ekonomistów. Do najbardziej dotkliwych dysfunkcji współczesnej gospodarki Elżbieta Mączyńska zalicza właśnie zagrożenia wynikające $\mathrm{z}$ nadmiernego zadłużania się ${ }^{2}$. Robert J. Shiller wskazuje zaś, że nadmierne zadłużenie, czyli takie, którego relacja do własnych zasobów staje się zbyt wysoka, może wręcz uniemożliwiać jakiekolwiek pozytywne działania. To nadmierne zadłużenie określa jako „nawis zadłużenia” (debt overhang) ${ }^{3}$. Również Jerzy Hausner przestrzega, że bez długookresowej perspektywy rozwojowej łatwo wpaść w pułapkę - tak jak wpada w nią każdy, kto nadmiernie zadłuży się, finansując swoje działania ze środków przejściowych ${ }^{4}$. Przyczyny nadmiernego długu i deficytu mogą mieć różne uwarunkowania, ich wspólnym mianownikiem jest jednak brak umiaru w wydatkach w relacji do dochodów ${ }^{5}$.

Długookresowa analiza sald budżetów państw rozwiniętych gospodarek rynkowych wskazuje, że deficyt oraz będące jego konsekwencją długi publiczne są trwała cechą struktury finansowej gospodarki ${ }^{6}$. Deficyty budżetowe, będące jednym z narzędzi państwowego interwencjonizmu, doprowadziły do znacznego wzrostu długu publicznego. Ten z kolei rodzi w przyszłości konieczność przeznaczania środków publicznych na jego spłatę lub też zaciagania w tym

${ }^{1}$ M. Poniatowicz et al., Efektywne zarzadzanie dtugiem $w$ jednostce samorzadu terytorialnego, Oficyna Wolters Kluwer business, Warszawa 2010, s. 11.

2 E. Mączyńska, Wybrane globalne i makroekonomiczne czynniki ksztattujace $w$ Polsce dochodzenie praw z umów, „Biuletyn PTE” 2015, nr 1(68), s. 21.

${ }^{3}$ R. J. Shiller, Finance and the Good Society, PUP, Princeton 2012, s. 151-159.

${ }^{4}$ M. Słodowa-Hełpa, Rozwój zintegrowany. Warunki, wymiary, wyzwania, CeDeWu, Warszawa 2013, s. 202.

${ }^{5}$ J. Pach, Umiar $w$ finansach publicznych $w$ świetle kryteriów budżetowych $z$ Maastricht, w: J. Pach et al. (red.), Ekonomia umiaru. Realna perspektywa? Nowy paradygmat Grzegorza W. Kotodki, PWN, Warszawa 2016, s. 168.

${ }^{6}$ S. Owsiak, Finanse, Polskie WE, Warszawa 2015, s. 320. 
celu kolejnego długu. Ta druga sytuacja określana jest rolowaniem długu, które może grozić wpadnięciem w pułapkę zadłużenia ${ }^{7}$.

Problem ten zauważyli i podkreślili autorzy raportu „Państwo i My. Osiem grzechów głównych Rzeczpospolitej”, wskazując, że każde spowolnienie gospodarcze, nieuniknione w gospodarce rynkowej, prowadzi do gwałtownego wzrostu poziomu długu, a po każdym kolejnym spowolnieniu jego wolumen pozostaje na znacznie wyższym poziomie i nie udaje się go odczuwalnie obniżyć. Może to spowodować, że realne stanie się wpadnięcie przez Polskę w pułapkę zadłużenia, która może nawet zagrozić niewypłacalnością .

Choć charakter zadłużenia samorządowego oraz przyczyny jego powstawania są znacząco różne od długu na poziomie państwa, to wspomniana problematyka dotyczy również szczebla regionalnego i lokalnego. Zadłużenie to jest nierozerwalnie związane z procesami rozwojowymi i stanowi przede wszystkim efekt zwiększonego wysiłku inwestycyjnego, będącego konsekwencją absorpcji środków pomocowych ${ }^{9}$. Pomimo to zagadnienia związane z refinansowaniem długu (powszechnie zwanym rolowaniem) mają odniesienie również do szczebla regionalnego i lokalnego.

O wyborze problematyki refinansowania zadłużenia samorządowego zadecydowało przeświadczenie autora o niedostatecznym ujmowaniu tego zagadnienia w literaturze przedmiotu, nierzadko jego bagatelizowaniu w odniesieniu do szczebla lokalnego oraz regionalnego i istnieniu pokaźnych luk na tym polu badawczym.

Cele niniejszego opracowania maja zarówno charakter poznawczy, jak i aplikacyjny. Zamierzeniem autora było usystematyzowanie informacji dotyczących refinansowania długu publicznego, w szczególności samorządowego, zbadanie skali tego zjawiska w polskich gminach oraz przedstawienie na tej podstawie propozycji wzbogacenia mierników oceny kondycji finansowej samorządów o wskaźniki uwzględniające analizowane zjawiska.

Tak nakreślonym celom podporządkowana została struktura opracowania. $\mathrm{Na}$ tle trudności związanych z pomiarem zadłużenia publicznego zaprezentowane zostało pojęcie refinansowania długu, z odniesieniem go do długu samorządowego. Zasygnalizowane też zostały zagadnienia związane z restrukturyzacją zadłużenia, myloną czasem z jego refinansowaniem. W kolejnej części opracowania przedstawiona została skala zjawiska refinansowania polskich gmin w latach 2003-2015 oraz propozycje mierników tego zjawiska. W podsumowaniu znalazły się najważniejsze wnioski oraz zidentyfikowane problemy wymagające dalszych badań.

\footnotetext{
${ }^{7}$ Ibidem, s. 83.

8 J. Hausner, S. Mazur (red.), Państwo i My. Osiem grzechów głównych Rzeczpospolitej, Fundacja Gospodarki i Administracji Publicznej, Kraków 2015, s. 71.

${ }^{9}$ W każdym roku okresu 2007-2012 inwestycje samorządowe przekraczały 50\% wydatków inwestycyjnych polskiego sektora publicznego. Por. K. S. Cichocki, Zarzadzanie finansami i dtugiem samorzadu terytorialnego w perspektywie wieloletniej, PAN, IBN, Warszawa 2013, s. 15.
} 


\section{TRUDNOŚCI ZWIĄZANE Z POMIAREM ZADŁUŻENIA PUBLICZNEGO}

Podczas analizy zagadnień związanych z zadłużeniem publicznym pamiętać należy, że jego znaczna część znajduje się poza statystyką publiczna. Zidentyfikować można dwie podstawowe przyczyny tego stanu rzeczy. Po pierwsze, w obowiązującym stanie prawnym długiem publicznym sa jedynie zobowiązania jednostek sektora finansów publicznych. Zobowiąania podmiotów nienależących do tego sektora, nawet gdy w całości stanowią one własność podmiotów publicznych, nie stanowią długu publicznego. Przesądza o tym zarówno literalne brzmienie art. 72 u.f.p. ${ }^{10}$, jak i wydanego na jego podstawie rozporządzenia wykonawczego ${ }^{11}$. Druga przyczyną jest korzystanie podmiotów sektora finansów publicznych ze zobowiązań o charakterze zwrotnym, które czasem słusznie, a czasem niesłusznie - nie są zaliczane do długu publicznego.

Wojciech Gonet wskazuje, że faktyczny dług publiczny składa się z długu oficjalnego i pozostałego, ten pozostały występuje zaś z większym stopniu w sektorze samorządowym niż rządowym ${ }^{12}$. Częste próby ominięcia ustawowych ograniczeń przez wykorzystywanie nienazwanych umów wywołujących skutki ekonomiczne podobne do umowy pożyczki lub kredytu spowodowały, że w grudniu 2010 r. Minister Finansów wydał rozporządzenie w sprawie szczegółowego sposobu klasyfikacji tytułów dłużnych zaliczanych do państwowego długu publicznego, w tym do długu Skarbu Państwa, które miało wyeliminować próby obchodzenia obowiązującego prawa ${ }^{13}$. Problem jest ciąle aktualny, na co wskazują m.in. wyniki kontroli przeprowadzanych przez regionalne izby obrachunkowe ${ }^{14}$. W'śód metod omijania ustawowych regulacji w zakresie korzystania z zobowiązań zwrotnych wymienia się przede wszystkim: finansowanie kapitałowe, sprzedaż zwrotna, leasing zwrotny, płatność ratalną oraz subrogację. Dodać należy, że zmieniające się otoczenie

${ }^{10}$ Ustawa z 27 sierpnia 2009 r. o finansach publicznych, Dz. U. 2016, poz. 1870 ze zm. (dalej jako: u.f.p.).

${ }_{11}$ Rozporządzenie Ministra Finansów z 28 grudnia 2011 r. w sprawie szczegółowego sposobu klasyfikacji tytułów dłużnych zaliczanych do państwowego długu publicznego, Dz. U. Nr 298, poz. 1767.

${ }_{12} \mathrm{~W}$. Gonet, Zapis dyskusji panelowej na temat „Pożadane kierunki i scenariusze naprawy finansów publicznych w Polsce”, w: J. Szołno-Koguc, A. Pomorska (red.), Ekonomiczne i prawne uwarunkowania $i$ bariery redukcji deficytu $i$ długu publicznego, Wolters Kluwer business, Warszawa 2011, s. 39.

${ }^{13}$ Szerzej na ten temat zob. M. Bitner, M. Kulesza, Nowa definicja państwowego dtugu publicznego? Problemy zwiazane z interpretacja przepisów rozporzadzenia Ministra Finansów z 23.12.2010 r. w sprawie szczegółowego sposobu klasyfikacji tytułów dłużnych zaliczanych do państwowego dtugu publicznego, w tym do dtugu Skarbu Państwa, „Samorząd Terytorialny” 2011, nr 7-8, s. 15-30; W. Miemiec, Kategoria kredytu i pożyczki jako tytutów zaliczanych do państwowego dtugu publicznego $w$ ustawie o finansach publicznych $i w$ rozporzadzeniu wydanym na jej podstawie, w: J. Szołno-Koguc, A. Pomorska (red.), op. cit., s. 183-196.

${ }^{14}$ T. Żółciak, Kreatywna księgowość kwitnie $w$ samorzadach. Nowe reguty zadtużenia się nie zdaja egzaminu, 2016, serwisy.gazetaprawna.pl/samorząd/artykuly/925758.html [dostęp: 22.02.2017]. 
powoduje, że pojawiają się całkiem nowe wątpliwości. Wystarczy wspomnieć chociażby o ewidencjonowaniu zobowiązań z tytułu emisji obligacji przychodowych przez jednostki samorządu terytorialnego w przypadku nieograniczenia odpowiedzialności emitenta wyłącznie do określonych przychodów i majątku ${ }^{15}$.

Na dług publiczny związany z jednostkami samorządu terytorialnego (dalej: JST) składają się w ostatnich latach przede wszystkim zobowiązania tych jednostek oraz ich związków, stanowiące ponad 95\% całej kwoty zadłużenia JST. Pozostała część zadłużenia stanowią głównie zobowiązania samodzielnych publicznych zakładów opieki zdrowotnej. Znaczna część długu (co najgorsze, istnieje obawa, że nikt dokładnie nie wie, jaka ${ }^{16}$ ) związanego z samorządowymi szpitalami została przetransferowana poza sektor finansów publicznych poprzez spółki specjalnego przeznaczenia ${ }^{17}$. Pamiętać również należy o zobowiązaniach dłużnych związanych z JST niestanowiacych jednak długu publicznego, a więc o zadłużeniu spółek komunalnych. W obowiązującym stanie prawnym zadłużenie spółek komunalnych nie podlega ograniczeniom ustawowym, ponadto próby badania jego wielkości i struktury są wyraźnie utrudnione. Brak również precyzyjnych danych dotyczących tych zobowiązań. Znaleźć można szacunki w tym zakresie ${ }^{18}$, niemniej skala zadłużenia spółek komunalnych nie jest do końca znana. Co więcej, w licznych opracowaniach formułowane są obawy, że wolumen tego zadłużenia ma charakter rosnący. Zaostrzające się regulacje w zakresie samorządowego zadłużenia mogą powodować, że część samorządów będzie transferować swój dług do spółek komunalnych ${ }^{19}$, w efekcie czego dług ten znajdzie się poza oficjalną statystyka. Zupełny brak regulacji we wskazanym zakresie stanowi poważne zagrożenie dla bezpieczeństwa finansowego samorządów.

Zadłużenie znajdujące się poza oficjalną statystyką nie jest wyłącznie problemem szczebla samorządowego. W ostatnich latach oficjalny państwowy dług publiczny Polski nieznacznie przekracza poziom 50\% PKB. Znaleźć można jednak publikacje wskazujące na znacznie wyższy jego poziom. Według Pawła Dobrowolskiego zadłużenie Polski wynosi ponad $200 \% \mathrm{PKB}^{20}$, co wynika również ze specyfiki ewidencjonowania zdarzeń gospodarczych przez sektor pub-

${ }_{15}$ M. Wiśniewski, Obligacje podporzqdkowane, wieczyste i przychodowe w Polsce-próba oceny ekonomicznych skutków nowelizacji ustawy o obligacjach, „Ruch Prawniczy, Ekonomiczny i Socjologiczny" 77, 2016, z. 1, s. 192.

${ }_{16}$ A. Kamela-Sowińska, Sekurytyzacja jako metoda oddtużenia polskich szpitali, „Zeszyty Naukowe Uniwersytetu Szczecińskiego” Finanse, Rynki Finansowe, Ubezpieczenia” 2014, nr 67, s. 911 .

17 Przykładem może być operacja dokonana przez Miasto Grudziądz w grudniu 2016 r.

18 Badania przeprowadzone przez A. Babczuka wskazuja, że na koniec 2010 r. tylko niespełna $76 \%$ zadłużenia związanego z samorządami dotyczyło samych JST, ponadto nieco ponad $18 \%$ stanowiły zobowiązania spółek komunalnych - zob. A. Babczuk, Zadłużenie spółek komunalnych w Polsce. Próba oceny skali i zróżnicowania regionalnego, „Finanse Komunalne” 2012, nr 9, s. 5-16.

${ }_{19}$ O procesie transferowania długu do spółek komunalnych zob. M. Bitner, Spółki prawa handlowego-przeniesienie zadtużenia poza JST, w: P. Walczak (red.), Zadtużenie jednostek samorzadu terytorialnego, C. H. Beck, Warszawa 2014, s. 235-260.

20 P. Dobrowolski, Prawdziwy dtug publiczny Polski wynosi ponad 200\% PKB, Instytut Sobieskiego, Warszawa 2009, sobieski.org.pl/wp-content/uploads/raport_dobrowolski_e_book.pdf [dostęp: 6.02.2017]. 
liczny. Księgowanie swych zobowiązań dopiero w roku wypłaty gotówki, a nie $\mathrm{w}$ momencie powstawania zobowiązania, zafałszowuje w znacznym stopniu dane dotyczące zadłużenia sektora publicznego. Jeszcze dalej w szacunkach tego długu idzie Leszek Balcerowicz. Uwzględniając zobowiązania legislacyjne niemajace pokrycia w papierach skarbowych, szacuje on, że całkowite zadłużenie Polski wynosi aż $250 \% \mathrm{PKB}^{21}$. Szacunki te mogą być zbyt pesymistyczne, niemniej bez wątpienia część zobowiązań podmiotów publicznych znajduje się poza oficjalną statystyka, co może wiązać się z potencjalnymi zagrożeniami zarówno dla poszczególnych podmiotów, jak też polskiej gospodarki.

\section{REFINANSOWANIE ZADŁUŻENIA}

Przez pojęcie refinansowania należy rozumieć operację pieniężną polegająca na pozyskaniu zewnętrznych źródeł finansowania w celu zastapienia środków własnych, które zostały wydatkowane na jakiś cel ${ }^{22}$. Według Kamilli Marchewki-Bartkowiak refinansowanie długu jest to wykup zapadajacego w danym roku zadłużenia w wyniku ponownego zaciagnięcia zobowiązań; może mieć ono charakter zarówno jednorazowy, jak też ciagły ${ }^{23}$. Pojęcie to nie posiada definicji formalnoprawnej, niemniej w przypadku długu publicznego odnoszone jest prawie wyłącznie do długu Skarbu Państwa. W ocenie Przemysława Wielgosza, problemem polskiego długu nie jest ani jego wielkość, ani realny ciężar, lecz problem politycznej decyzji promującej obsługę interesów finansjery kosztem zaspokajania potrzeb społecznych i rozwoju gospodarczego ${ }^{24}$. Większość długu przeznaczana jest na spłatę starych długów. Ze statystyk Ministerstwa Finansów wynika bowiem, że od połowy do dwóch trzecich potrzeb pożyczkowych Polski związana jest z koniecznością obsługi długu Skarbu Państwa. Dodać należy, że zjawisko refinansowania długów jest powszechne i dotyczy zdecydowanej większości krajów.

Pomimo że zadłużenie jednostek samorządu terytorialnego, stanowiące część państwowego długu publicznego ${ }^{25}$, jest od kilkunastu lat przedmiotem licznych publikacji, to kwestie związane z refinansowaniem tego długu znajdują się poza obszarem zainteresowań badaczy. Brak ogólnodostępnych danych, niedostosowana sprawozdawczość oraz klasyfikacja budżetowa po-

21 A. Koziński, Balcerowicz pokazuje prawdziwy dtug Polski, 2013, polskatimes.pl/artykul.1005111.html [dostęp: 6.02.2017].

${ }_{22}$ Refinansowanie, Portal Narodowego Banku Polskiego, www.nbportal.pl/slownik/pozycje-slownika/refinansowanie [dostęp: 8.02.2017].

${ }^{23}$ K. Marchewka-Bartkowiak, Refinansowanie (rolowanie) długu, 2012, sejm.gov.pl/sejm7. nsf/BAS Leksykon [dostęp: 8.02.2017].

${ }^{24}$ P. Wielgosz (red.), Kryzys długów publicznych. Przewodnik dla poczatkujacych, witryna Polskiego Towarzystwa Ekonomicznego, 2012, issuu.com/lmdpl/docs/dlug [dostęp: 22.02.2017].

${ }_{25}$ Zadłużenie JST stanowi od kilku lat około 8\% państwowego długu publicznego, jest to poziom wyraźnie niższy od pozostałych krajów należących do Unii Europejskiej - więcej zobacz B. Filipiak, Przestanki dokonania oceny samorzqdowego dtugu publicznego na tle podejścia badawczego, w: E. Denek, M. Dylewski (red.), Szacowanie poziomu zadtużenia jednostek samorzadu terytorialnego $w$ warunkach zwiększonego ryzyka utraty płynności finansowej, Difin, Warszawa 2013, s. $176-177$. 
woduja, że aby te zjawiska badać, potrzebna jest duża znajomość zagadnień praktycznych związanych z finansami samorządowymi. Proces refinansowania długu zwany jest również rolowaniem długu. W tym kontekście bywa on odnoszony do długu samorządowego, niemniej odniesienia te sa z reguły lakoniczne. Zaciaganie zobowiązań w celu spłaty już istniejących (czyli właśnie rolowanie długu) świadczy o aktualnie występującej niemożności uregulowania dotychczasowych zobowiązań z posiadanych środków, co prowadzić może do wpadnięcia w tzw. pułapkę zadłużeniową ${ }^{26}$, określaną również spiralą zadłu$\dot{z ̇ e n i a}^{27}$. Pojęcie rolowania długu ma zdecydowanie bardziej pejoratywne konotacje, niemniej wskazuje się, że może ono mieć również pozytywne skutki ekonomiczne. Stać się tak może w przypadku refinansowania długu droższego długiem tańszym. Notoryczne rolowanie długu może jednak prowadzić do niemożności spłaty zadłużenia z własnych środków ${ }^{28}$.

Możliwość zaciagania zobowiązań przeznaczonych na spłatę zobowiązań wcześniej zaciąniętych z tytułu emisji papierów wartościowych oraz pożyczek i kredytów polskie samorządy uzyskały w przeddzień przystapienia do struktur zjednoczonej Europy. Na mocy ustawy z 17 października 2003 r. o zmianie ustawy o finansach ${ }^{29}$ publicznych został bowiem rozszerzony katalog celów, jakim zobowiązania zwrotne miały służyć. Według Wojciecha Goneta ${ }^{30}$ legalizacja zaciagania długu na spłatę istniejącego już zadłużenia może prowadzić do rolowania długu przez wiele lat lub nawet w sposób ciagły. Zaciaganie długu na spłatę istniejących zobowiązań może być jednak również korzystne. Stanie się tak w przypadku, gdy nowy dług udostępniony zostanie na korzystniejszych warunkach. Pomimo licznych, istotnych zmian w zakresie stanu prawnego regulującego kwestie długu publicznego możliwość refinansowania długu samorządowego pozostała niezmieniona do dnia obecnego.

Jednym z podstawowych typów ryzyka związanych z rządowym długiem publicznym jest ryzyko refinansowania ${ }^{31}$. Jako jego miarę wskazuje się średni okres wymagalności zobowiązań (ATM - average time to maturity). Stanowi on wyrażoną w latach średnią długość okresu, po którym zaciagnięty dług jest spłacany ${ }^{32}$. Co ciekawe, wśród licznych rodzajów ryzyka wskazywanych w publikacjach dotyczących zarządzania samorządowym długiem publicznym nie wskazuje się ryzyka refinansowania ${ }^{33}$.

${ }^{26}$ M. Cilak, Instrumenty wspierania rozwoju gospodarczego stosowane przez samorzqd terytorialny. Problematyka prawnofinansowa, TNOiK, Dom Organizatora, Toruń 2013, s. 205.

27 M. Jastrzębska, Nadmierne zadłużanie się jednostek samorzadu terytorialnego-przyczyny, skutki, przeciwdziatanie, „Finanse Komunalne” 2016, nr 6, s. 18.

${ }_{2}$ M. Tyniewicki, Ogólne zasady zaciagania zobowiazań przez inne niż Skarb Państwa jednostki sektora finansów publicznych, w: E. Ruśkowski, J. M. Salachna (red.), Finanse publiczne. Komentarz praktyczny, ODDK, Gdańsk 2014, s. 420-421.

29 Dz. U. 2003, Nr 189, poz. 1851.

${ }^{30}$ W. Gonet, Kredyty, pożyczki, obligacje $w$ gospodarce finansowej samorzqdu terytorialnego, Szkoła Główna Handlowa w Warszawie - Oficyna Wydawnicza, Warszawa 2006, s. 83-84.

31 Taki pogląd prezentują m.in. K. Marchewka-Bartkowiak oraz T. Uryszek w pracach wymienionych w niniejszym tekście.

${ }^{32}$ T. Uryszek, Ryzyko refinansowania długu Skarbu Państwa w Polsce, Finanse i Prawo Finansowe 2, Łódź 2014, finanseiprawofinansowe.uni.lodz.pl/Publikacje/2/Dodatek_Kwartalny.pdf [dostęp: 8.02.2017].

33 Zob. M. Poniatowicz, Dług publiczny w systemie finansowym jednostek samorzadu tery- 
Refinansowanie długu wiązane jest również z pojęciem potrzeb pożyczkowych budżetu, zdefiniowanym w u.f.p. i dotyczacym budżetu państwa. Potrzeby pożyczkowe budżetu państwa to zapotrzebowanie na środki niezbędne do sfinansowania deficytów budżetu państwa, budżetu środków europejskich oraz rozchodów budżetu państwa. Minister Finansów cyklicznie publikuje dane dotyczące tych potrzeb, niemniej dotyczą one jedynie budżetu państwa. Pozostałe jednostki sektora finansów publicznych takich danych niestety nie publikuja. Postulaty prezentowania wskaźnika łącznych potrzeb pożyczkowych całego polskiego sektora finansów publicznych ${ }^{34}$ pojawiają się w przestrzeni publicznej, niestety nie są one liczne.

\section{RESTRUKTURYZACJA ZADŁUŻENIA}

Podobnie jak refinansowanie, również restrukturyzacja zadłużenia nie została prawnie uregulowana. Bywa ona mylona zarówno z pojęciem zarządzania długiem publicznym, jak i z jego refinansowaniem ${ }^{35}$.

W publikacjach zarówno o charakterze naukowym ${ }^{36}$, jak i publicystycznym ${ }^{37}$ znaleźć można opinie o niedopuszczalności traktowania analizowanych procesów jako zaciagnięcia zobowiązania zwrotnego. Wymieniony w ustawie o finansach publicznych katalog identyfikujący cele, dla których samorządy moga zaciagać zobowiązania dłużne, jest katalogiem zamkniętym. Zawieranie umów kredytów konsolidacyjnych nie jest pozabilansową operacją na długu, a stanowi obejście przepisów w zakresie limitowania długu JST. Operacja konsolidacji długu nie stanowi odrębnego tytułu uprawniającego do zaciagania zobowiązań dłużnych. W konsekwencji procesy konsolidacyjne stają się w większości przypadków niemożliwe do przeprowadzenia ze względu na obowiązujące przepisy. Próba konsolidacji nawet niewielkiej części zadłużenia kończy się bowiem niespełnieniem obowiązujących limitów ilościowych. Kwestie dopuszczalności rozwiązań, o których mowa powyżej, nie są przedmiotem licznych rozważań, niemniej znaleźć można również poglądy, że są one nie tylko dozwolone, ale nie wymagają również ich ewidencjonowania jako zaciagnięcia zobowiązań dłużnych. Pogląd taki wyraża m.in. Józef Stęplowski ${ }^{38}$. W jego ocenie przyjęcie od-

torialnego (na przyktadzie miast na prawach powiatu), Wyd. UwB, Białystok 2005, s. 253-259; M. Poniatowicz et al., Efektywne zarzadzanie dtugiem w jednostce samorzadu terytorialnego, Wolters Kluwer business, Warszawa 2010, s. 118-148.

${ }^{34}$ K. Marchewka-Bartkowiak, Potrzeby pożyczkowe jednostek sektora finansów publicznych, INFOS, Biuro Analiz Sejmowych, 2012, orka.sejm.gov.pl/Infos_131.pdf [dostęp: 6.02.2017].

${ }^{35}$ Artykut 243. Ze skarbnikiem o ustawie o finansach publicznych, 2013, Serwis Samorządowy PAP, samorzad.pap.pl/depesze/wiadomości_centralne/125229 [dostęp: 22.02.2017].

${ }^{36}$ M. Tyniewicki, Ogólne zasady zaciagania zobowiazań przez inne niż Skarb Państwa jednostki sektora finansów publicznych, w: E. Ruśkowski, J. M. Salachna (red.), op. cit., s. 418-419.

${ }^{37} \mathrm{P}$. Walczak, Zasady zaciagania zobowiqzań z tytułu kredytów, pożyczek i papierów wartościowych przez zarzady JST, w: P. Walczak (red.), Zadtużenie jednostek samorzadu terytorialnego, C. H. Beck, Warszawa 2014, s. 154-156.

${ }^{38} \mathrm{~J}$. Stęplowski, Czy kredyt konsolidacyjny wymaga zmiany budżetu jednostki samorzadu terytorialnego?, „Finanse Komunalne” 2016, nr 6, s. 62. 
miennego punktu widzenia prowadzi do stawiania znaku równości pomiędzy zaciaganym kredytem tworzącym dług i jego przeznaczeniem na spłatę starego długu, a w rzeczywistości są to dwie odrębne kategorie ekonomiczne. Wskazać należy, że taki swoisty znak równości postawił Minister Finansów, opracowując klasyfikację dochodów, wydatków, przychodów oraz rozchodów budżetowych, w której przychody z tytułu kredytów i pożyczek ewidencjonowane są w tej samej podziałce klasyfikacji budżetowej, w przypadku zarówno tych zaciaganych w celu finansowania planowanego deficytu budżetu, jak i służących spłacie zobowiązań z tytułu zaciagniętych $\mathrm{w}$ latach poprzednich kredytów i pożyczek. Wskazać trzeba również na zaproponowany w 2014 r. przez Polskie Stronnictwo Ludowe projekt zmian przepisów regulujących gospodarkę finansową samorządów ${ }^{39}$. Projekt przewidywał m.in. umożliwienie zaciagania przez JST kredytów konsolidacyjnych. Ten projekt poselski zaproponowany, co ważne, przez partię tworząca koalicję rządową nie uzyskał jednak aprobaty Ministra Finansów, co nie pozwoliło na dalsze jego procedowanie. Fakt ten nie stanowi bynajmniej potwierdzenia stanowiska, że procesy konsolidacji/restrukturyzacji samorządowego zadłużenia są bezwzględnie dopuszczalne i nie wymagają ewidencjonowania zobowiązań z tego tytułu jako zobowiązań dłużnych.

Przedstawiony problem ma swoje źródło w stanie prawnym, przepisy nie regulują bowiem, do jakich operacji na długu uprawnione są samorządy. Wniosek de lege ferenda $\mathrm{w}$ zakresie pilnego uregulowania zagadnień związanych $\mathrm{z}$ restrukturyzacją/konsolidacją samorządowego zadłużenia ${ }^{40}$ formułowany jest coraz częściej.

\section{REFINANSOWANIE ZADŁUŻENIA POLSKICH GMIN W LATACH 2003-2015}

Przedmiot zaprezentowanych $\mathrm{w}$ tekście badań stanowią zobowiązania zwrotne zaciagane przez polskie gminy w powiązaniu z generowanymi nadwyżkami operacyjnymi. $\mathrm{Na}$ tej podstawie dokonano oceny skali zjawiska refinansowania długu oraz zaproponowano wskaźniki, jakie moga służyć jego pomiarowi. Podmiotem badań były wszystkie polskie gminy, a więc stała grupa w całym okresie objętym analiza, licząca 2478 obiektów badawczych. W warunkach globalizacji kontekst lokalny nie traci bynajmniej na znaczeniu. Zdaniem wnikliwych badaczy problemów rozwojowych, paradoksalnie zyskuje on wręcz na znaczeniu ${ }^{41}$.

Ze względu na specyfikę gminy podzielone zostały na dwie grupy: miasta na prawach powiatu (66 obiektów badawczych) oraz pozostałe gminy (2412 obiektów). O wyodrębnieniu grupy miast na prawach powiatu zdecydowały

${ }^{39}$ A. Gniadkowski, Poprawianie artykułu 243: samorzqdy pod mniejsza presja, „Wspólnota” 2014, nr 19, s. 38-39.

40 R. P. Krawczyk, Problem skuteczności rozwiazań prawnych zapobiegajacych nadmiernemu zadłużaniu się samorzadu terytorialnego, „Finanse Komunalne” 2016, nr 12, s. 18; D. Jurewicz, Dług samorzadu - bodziec czy bariera absorpcji środków europejskich?, „Ruch Prawniczy, Ekonomiczny i Socjologiczny" 78, 2016, z. 2, s. 247.

${ }^{41}$ M. Słodowa-Hełpa, op. cit., s. 22. 
przede wszystkim trzy powody: zdecydowanie większy potencjał dochodowy, znacząco większa ilość realizowanych inwestycji oraz posiadanie w momencie rozpoczęcia badań dużo większego zadłużenia. Dodać trzeba, że w całym okresie objętym badaniem nie nastapiły zmiany w zakresie przynależności gmin do grup miast na prawach powiatu lub pozostałych gmin.

Badaniami objęty został okres od 2002 do 2015 r. O wyborze horyzontu czasowego przesądziły przede wszystkim dwa argumenty. Po pierwsze, była to dostępność danych. Badania wymagały dostępu do bardzo szczegółowych oraz rozległych danych, zelektronizowana wersja bazy danych ${ }^{42}$ dostępna jest właśnie od 2002 r. Dodatkowo w horyzoncie, jaki obejmuje praca, zobrazowano wybrane elementy związane z ogromnym wysiłkiem inwestycyjnym, jakiego polskie gminy dokonały w związku z absorpcją środków z budżetu Unii Europejskiej. Wysiłek ten nie byłby możliwy bez zwielokrotnienia posiadanego zadłużenia. W niniejszym opracowaniu zaprezentowane sa wyniki dla lat 20032015. Nie stanowi to jednak przejawu nieprzestrzegania przez autora jedności horyzontu czasowego. W celu zaprezentowania części danych dla 2003 r. (dotyczących zmiany poziomu zadłużeniu w odniesieniu do roku poprzedniego) konieczne bowiem było wykorzystanie wielkości dotyczących 2002 r.

W celu wyeliminowania czynnika zmiany wartości pieniądza w czasie zmienne zostały skorygowane o inflację ${ }^{43}$ i wszystkie sprowadzone do poziomu cen w 2015 r.

Na wykresach 1 i 2 przedstawiona została skala zjawiska refinansowania długu miast na prawach powiatu oraz pozostałych polskich gmin.

\section{Wykres 1}

Zobowiązania zwrotne zaciąnięte w poszczególnych latach a zmiana poziomu zadłużenia miast na prawach powiatu w latach 2003-2015 (w mln zł)

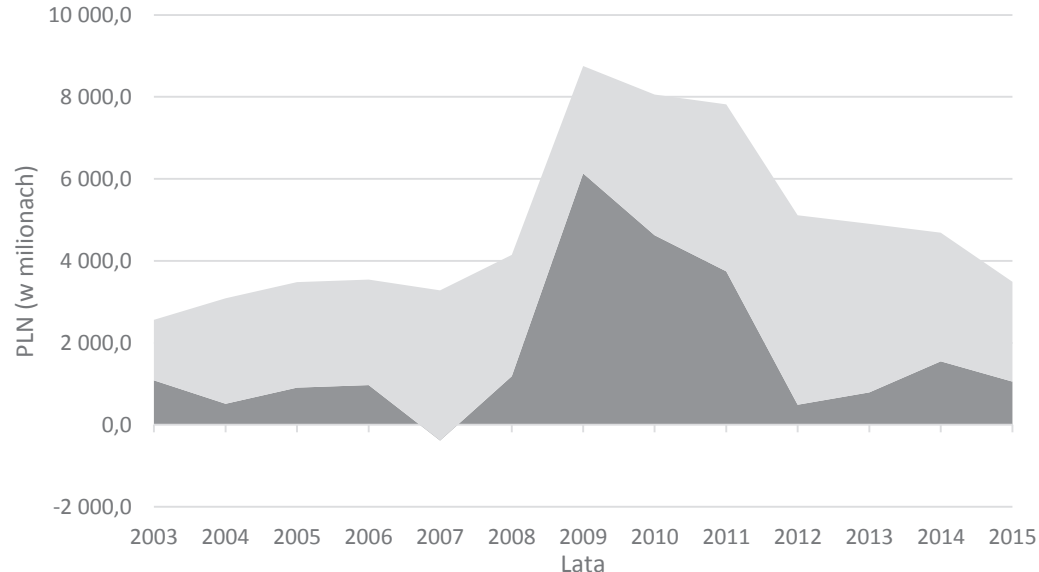

Źródło: obliczenia własne na podstawie danych ze sprawozdań budżetowych polskich gmin.

${ }^{42}$ Dane pochodzą z programu Besti@ należącego do ministra właściwego ds. finansów publicznych i zawierającego informacje ze sprawozdań sporządzonych przez jednostki samorządu terytorialnego.

${ }^{43}$ Dane w zakresie inflacji zaczerpnięto z informacji prezentowanych przez Główny Urząd Statystyczny (http://stat.gov.pl). 


\section{Wykres 2}

Zobowiązania zwrotne zaciagnięte w poszczególnych latach a zmiana poziomu zadłużenia gmin z wyłączeniem miast na prawach powiatu w latach 2003-2015 (w mln zł)

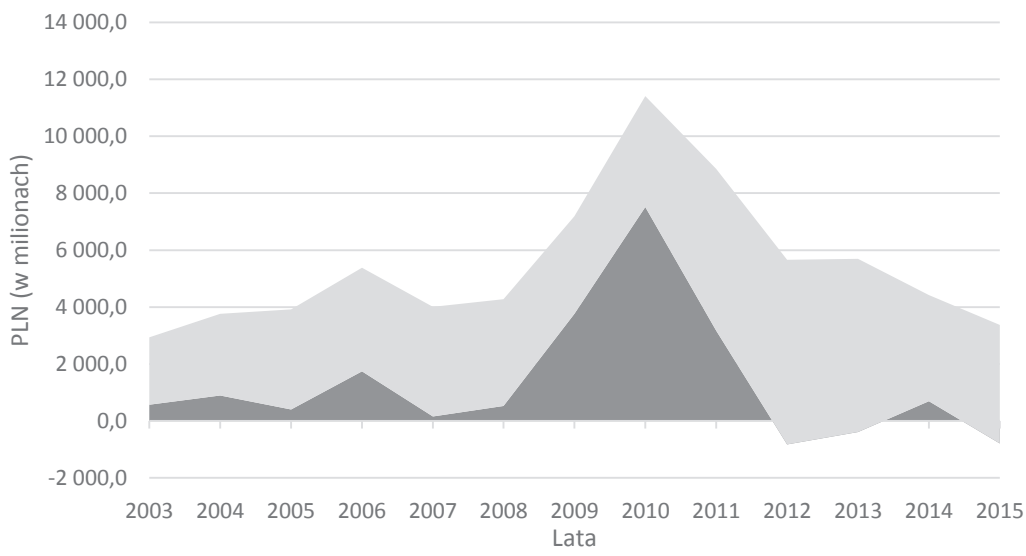

Źródło: obliczenia własne na podstawie danych ze sprawozdań budżetowych polskich gmin.

Wielkości zobrazowane na wykresach 1 i 2 kolorem ciemniejszym wskazują zmianę poziomu zadłużenia - a więc dane ogólnodostępne i prezentowane zarówno w licznych publikacjach naukowych, jak i doniesieniach medialnych. Wielkości przedstawione kolorem jaśniejszym prezentują skalę refinansowania długu polskich gmin. Z tej graficznej prezentacji wynika, że zaciaganie zobowiązań dłużnych na spłatę istniejącego już zadłużenia polskich gmin ma pokaźne rozmiary. Refinansowanie długu nie ma charakteru incydentalnego, lecz jest zjawiskiem o charakterze masowym. Zjawisko zdecydowanie szybciej widoczne jest w przypadku miast na prawach powiatu, co wskazywać może na silne powiązanie z wielkościa posiadanego zadłużenia. W obu grupach badanych gmin refinansowanie długu największe rozmiary przyjmuje po okresie silnego wzrostu zadłużenia, który nastapił w latach 2009-2011, niemniej nasila się ono najbardziej po około dwóch latach po tym wzroście. Efekty zadłużenia (również te niepożądane) pojawiają się często ze znacznym opóźnieniem. Dane wskazują również na konieczność poszukiwania nowych miar związanych z długiem - zaciaganie zobowiązań zwrotnych na spłatę zadłużenia nasiliło się najbardziej w momencie, gdy zadłużenie w wartościach nominalnych ustabilizowało się (a w grupie gmin z wyłączeniem miast na prawach powiatu zaczęło nawet spadać). Pomijanie danych w zakresie refinansowania zadłużenia samorządowego może znacząco wypaczać wyniki przeprowadzanych badań ${ }^{44}$.

\footnotetext{
${ }^{44}$ Autor prowadził badania w zakresie wpływu zadłużenia gmin na ich rozwój na przykładzie gmin województwa kujawsko-pomorskiego w latach 2003-2013. W wyniku uwzględnienia zaciagania zobowiązań na spłatę istniejącego długu siła korelacji między zobowiązaniami zwrotnymi a wydatkami inwestycyjnymi tych gmin jest zdecydowanie mniejsza niż prezentowana przez innych badaczy. Szerzej D. Jurewicz, op. cit., s. 231-249.
} 
Wielkościa, która dobrze obrazuje refinansowanie długu, sa potrzeby pożyczkowe budżetu. Miernikiem, który w opinii autora najlepiej obrazuje omawiane zjawisko i może być szeroko wykorzystany, są potrzeby pożyczkowe budżetu w przeliczeniu na mieszkańca ${ }^{45}$. Można go prezentować dla poszczególnych samorządów, jak też dla ich grup. Na wykresach 3 i 4 zaprezentowano wielkość tego wskaźnika dla wszystkich miast na prawach powiatu oraz pozostałych polskich gmin w porównaniu z prezentowanym w zdecydowanej większości publikacji wskaźnikiem obrazującym zadłużenie w przeliczeniu na mieszkańca.

\section{Wykres 3}

Zadłużenie oraz potrzeby pożyczkowe miast na prawach powiatu w przeliczeniu na mieszkańca w latach 2003-2015 (w zł)

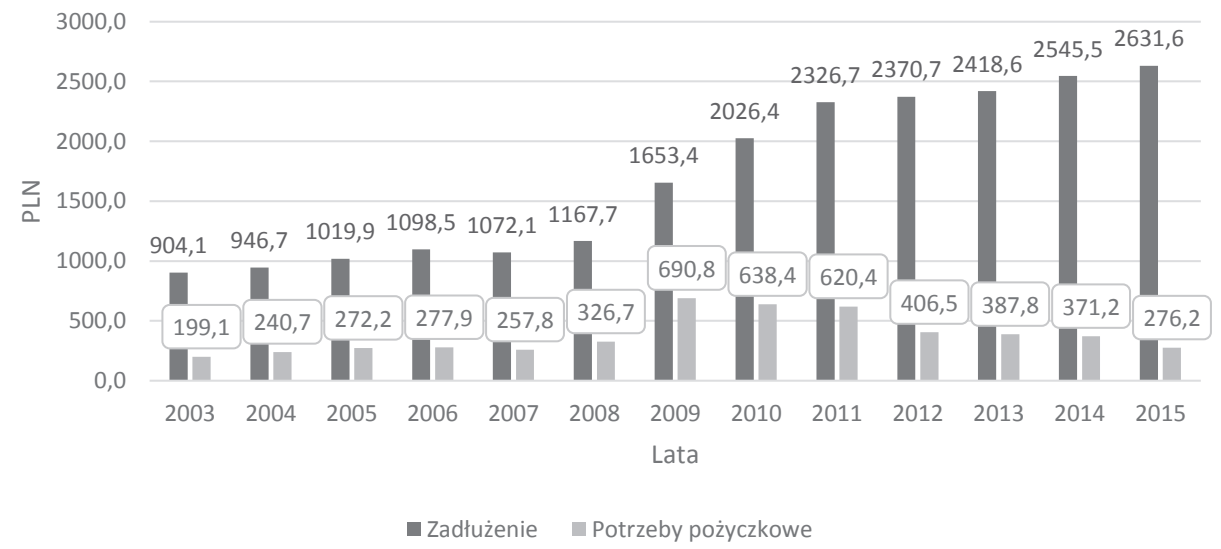

Źródło: obliczenia własne na podstawie danych ze sprawozdań budżetowych polskich gmin.

Nawet tylko pobieżna analiza obu zaprezentowanych powyżej wskaźników pozwala stwierdzić, że po pierwsze, potrzeby pożyczkowe budżetu są znaczne, a po drugie, że w poszczególnych latach ich relacja w stosunku do zadłużenia znacząco się różni. Dla przykładu w grupie gmin z wyłączeniem miast na prawach powiatu w 2010 r. zadłużenie na mieszkańca w przeliczeniu na mieszkańca było wyższe do potrzeb pożyczkowych na mieszkańca nieco ponaddwukrotnie, a w 2015 r. ponadsiedmioipółkrotnie. Potwierdza to zasadność wzbogacenia analizowanych przez badaczy wielkości o potrzeby pożyczkowe budżetu.

45 Aby uzyskać wartość wskaźnika, należy podzielić ilość zaciagniętych w danym okresie zobowiązań o charakterze zwrotnym (kredytów, pożyczek i wyemitowanych papierów wartościowych) przez liczbę mieszkańców. 


\section{Wykres 4}

Zadłużenie oraz potrzeby pożyczkowe budżetów w przeliczeniu na mieszkańca gmin z wyłączeniem miast na prawach powiatu w latach 2003-2015 (w zł)

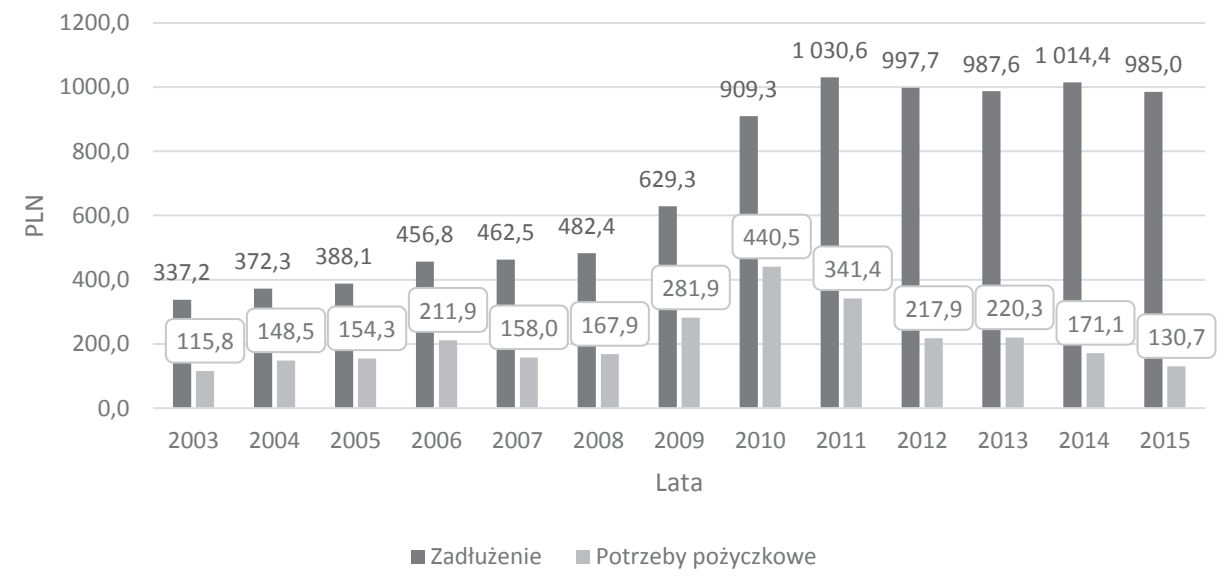

Źródło: obliczenia własne na podstawie danych ze sprawozdań budżetowych polskich gmin.

Wcześniej zaprezentowano, że zadłużenie państw analizowane jest z uwzględnieniem średniego okresu zapadalności zadłużenia. Im ten okres jest wyższy, tym wyższe jest ryzyko refinansowania długu. Metodyka obliczania takiego wskaźnika jest możliwa do zastosowania jedynie w odniesieniu do poszczególnych samorządów, nie ma jednak możliwości zastosowania go do ich grupy. Propozycja o bardzo uniwersalnym zakresie możliwości wykorzystania jest przedstawiony niżej okres spłaty zadłużenia nadwyżką operacyjna, jednym z najważniejszych wyznaczników oceny sytuacji finansowej samorządów stanowiącym różnicę między zrealizowanymi dochodami bieżącymi a wydatkami bieżącymi. Wielkość ta wskazuje, jak wiele środków finansowych generowanych przez dany samorząd pozostaje po sfinansowaniu jego bieżącego funkcjonowania. Obowiązujacca ustawa o finansach publicznych sprawiła, że polskie samorządy koncentrują swe działania na osiaganiu jak najwyższego poziomu nadwyżek operacyjnych. Od tej wielkości w największym stopniu zależy dopuszczalny poziom zadłużenia samorządów. To właśnie z nadwyżki operacyjnej samorządy mogą finansować działalność inwestycyjną lub dokonywać spłaty swego zadłużenia.

Dobrą miarą oceny zadłużenia samorządów może być wspomniany okres spłaty zadłużenia nadwyżką operacyjną. Okres ten uzyskać można, dzieląc posiadane na koniec danego roku zadłużenie przez osiagniętą w tym roku nadwyżkę operacyjna. Wskazuje on, ile czasu (liczonego w latach) zajęłaby JST spłata zadłużenia przy założeniu, że cała wygenerowana przez nią nadwyżka operacyjna zostałaby przeznaczona na spłatę zadłużenia. Podobnie jak wskaźnik potrzeb pożyczkowych w przeliczeniu na mieszkańca, zaproponowana miara ma charakter uniwersalny - może być zastosowana zarówno w odniesieniu do poszczególnych samorządów, jak też dowolnych ich grup. Na wykresie 5 zaprezentowano wartość wspomnianego okresu dla polskich miast na prawach powiatu, natomiast na wykresie 6 dla pozostałych gmin. 


\section{Wykres 5}

Okres spłaty zobowiązań nadwyżką operacyjną miast na prawach powiatu w latach 2003-2015

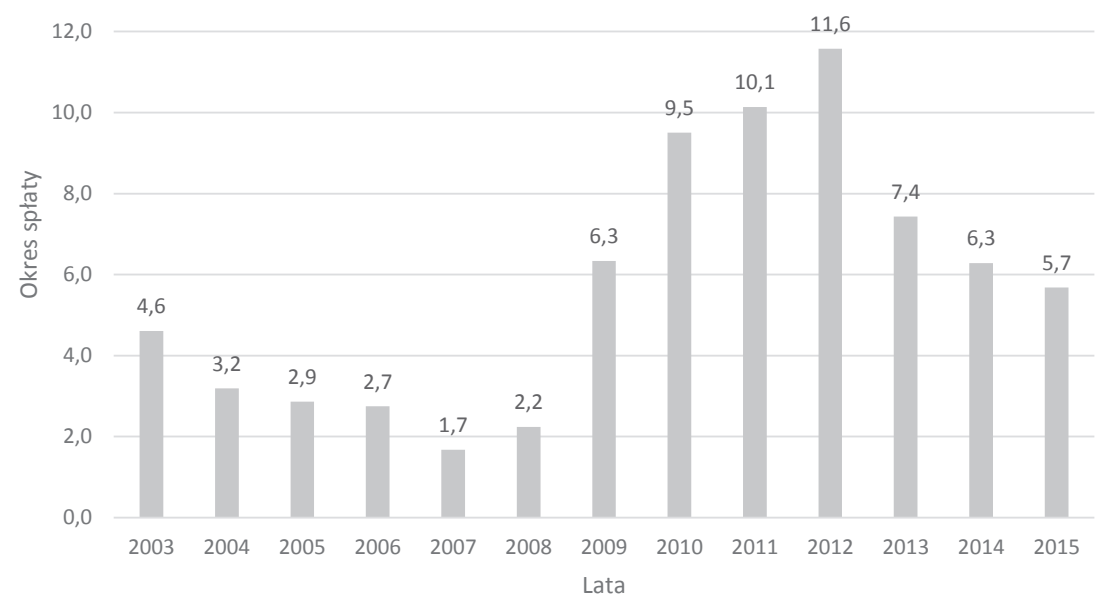

Źródło: obliczenia własne na podstawie danych ze sprawozdań budżetowych polskich gmin.

\section{Wykres 6}

Okres spłaty zobowiązań nadwyżką operacyjną gmin z wyłączeniem miast na prawach powiatu w latach 2003-2015 (w zł)

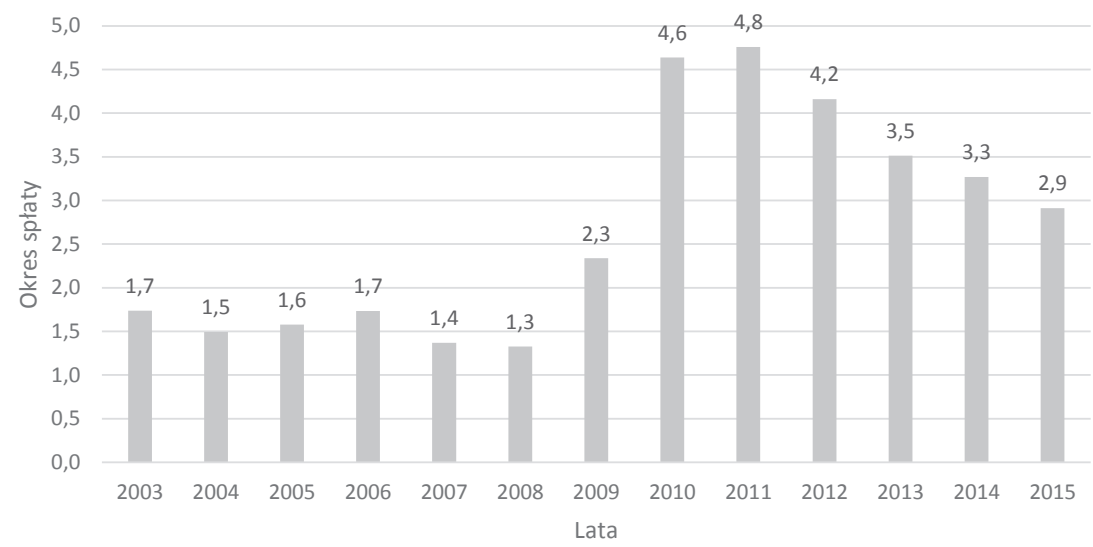

Źródło: obliczenia własne na podstawie danych ze sprawozdań budżetowych polskich gmin.

Dane zaprezentowane na wykresach 5 i 6 wskazuja, że w analizowanym horyzoncie czasowym okres spłaty zobowiązań charakteryzował się znaczną zmiennościa, po początkowo niskich wartościach, w latach 2009-2010 nastapił gwałtowny jego wzrost, po czym zaczałł ponownie maleć. Na wspomniany gwałtowny wzrost wpływ miał duży wzrost wolumenu posiadanego zadłużenia 
połączony z malejąca tendencją nadwyżek operacyjnych. Po 2010 r. wielkość zadłużenia ustabilizowała się, niemniej wyraźnie zaczął rosnąć poziom nadwyżek operacyjnych generowanych przez polskie gminy. Jak już wspomniano, dopuszczalny poziom zadłużenia samorządów zależy w głównej mierze od poziomów generowanych nadwyżek operacyjnych, rozwiązanie to zawarto w u.f.p. z 2009 r. Późniejszy wzrost tych nadwyżek wydaje się pozytywną konsekwencja zmiany stanu prawnego.

Z danych zaprezentowanych na wszystkich powyższych wykresach wyciagnąc można kilka najważniejszych wniosków. Po pierwsze, zjawisko refinansowania długu znacznie szybciej uwidoczniło się w grupie miast na prawach powiatu, co niewątpliwie spowodowane jest znacznie wyższym wyjściowym poziomem posiadanego zadłużenia. $Z$ wykresów 1 i 2 wynika również, że skala refinansowania długu nasila się wyraźnie po okresach znacznego wzrostu zadłużenia.

Po drugie, analiza zadłużenia samorządowego powinna uwzględniać potrzeby pożyczkowe. Wartości zaprezentowane na wykresach 3 i 4 wskazuja, że potrzeby te są bardzo wysokie, a ich wartość w porównaniu z całością zadłużenia gmin jest mocno zmienna w poszczególnych latach. Pomijanie tych danych może utrudniać wyciaganie właściwych wniosków z przeprowadzanych analiz.

Po trzecie, analiza samorządowego zadłużenia powinna odbywać się z wykorzystaniem okresu spłaty zadłużenia nadwyżką operacyjna, w szczególności jeśli chodzi o kwestie związane z szeroko pojętym bezpieczeństwem finansowym samorządów.

Ponadto z zadłużeniem samorządowym związane jest ryzyko refinansowania, którego dobrą miarą jest zaprezentowany okres spłaty zadłużenia nadwyżką operacyjną. Rosnący poziom zadłużenia samorządów powoduje wzrost ryzyka jego refinansowania.

\section{PODSUMOWANIE}

Refinansowanie długu w zdecydowanej większości przypadków jest świadomą suwerenną decyzją władz lokalnych. Dopóki polskie samorządy będą ponosiły zwiększony wysiłek finansowy związany z absorpcją środków z budżetu Unii Europejskiej, dopóty skala zjawiska nie będzie maleć. W takich przypadkach refinansowanie długu samorządowego, zwanego popularnie rolowaniem długu, nie powinno budzić poważnych obaw, niemniej skala zjawiska winna być monitorowania, czemu służyć powinny m.in. propozycje przedstawione w niniejszym tekście.

Wprawdzie istniejącego nawisu samorządowego zadłużenia nie należy jeszcze traktować jako uniemożliwiającego pozytywne działania, niemniej coraz częściej może on te działania utrudniać. Problem pojawia się w sytuacji, gdy refinansowanie długu staje się koniecznością - brak bowiem możliwości spłaty zadłużenia. Kolejna perspektywa budżetowa Unii Europejskiej i związany 
z nią przewidywany wzrost samorządowego zadłużenia mogą spowodować, że trudności te będą coraz bardziej odczuwalne.

Wnioskiem natury ogólnej, jaki wynika z niniejszego opracowania, jest nieprecyzyjność danych dotyczących polskiego zadłużenia publicznego. Nie wszystkie zobowiązania dłużne związane z podmiotami publicznymi ujęte są bowiem w ogólnej statystyce zadłużenia, a wielkość nieujętego zadłużenia może wyraźnie zmieniać się w czasie. Podmioty próbujące ukrywać zadłużenie powinny zaś brać pod uwagę ryzyko zmiany stanu prawnego - dobrym przykładem jest wskazana w tekście zmiana katalogu tytułów dłużnych dokonana w grudnia 2010 r. Nieunikniona reakcja ustawodawcy może bowiem spowodować negatywne konsekwencje dla poszczególnych samorządów.

W pełni zasadny jest wyrażony przez K. Marchewkę-Bartkowiak postulat dotyczacy publikowania danych dotyczących potrzeb pożyczkowych polskich samorządów. Analiza sytuacji finansowej polskich samorządów powinna być czyniona z uwzględnieniem dodatkowych wskaźników obrazujących kwestie refinansowania długu. Nie sposób nie zgodzić się z postulatem Doroty Jegorow, by praktyka sprawozdawcza oparta na wybiórczej prezentacji danych ilościowych została wyeliminowana z przestrzeni publicznej ${ }^{46}$. Przykładem takich nowych wskaźników mogą być zaproponowane w niniejszym tekście potrzeby pożyczkowe budżetu oraz okres spłaty zobowiązań nadwyżką operacyjna. Do grupy ryzyk związanych z długiem samorządowym dodać zaś należy ryzyko refinansowania.

Optyka zjawisk związanych z zadłużeniem zmienia się wraz ze zmieniającym się otoczeniem. Wskazać należy, że nawet Międzynarodowy Fundusz Walutowy, przez wielu uznawany za ostoję poglądów ekonomii ortodoksyjnej, zaleca, aby spłata długu nie odbywała się kosztem procesów rozwojo$w_{y c h}{ }^{47}$. Zmniejszanie zadłużenia publicznego nie powinno być celem samym w sobie i musi odbywać się z uwzględnieniem wielu czynników o charakterze społecznym.

W'́ród licznych problemów polskich samorządów wszystkich szczebli wymienić należy niewielki stopień ich samodzielności finansowej. Zdecydowana większość gmin wskazuje na potrzebę zwiększenia budżetów samorządowych, niemniej tylko co trzecia z nich źródeł zwiększonych dochodów upatruje w podatkach lokalnych ${ }^{48}$. To również może stanowić wyjaśnienie tak dużej popularności refinansowania długu samorządowego. „Łatwe pieniądze” nie zawsze są jednakże czynnikiem rozwojowym, a przestrogą niech będzie przykład największych beneficjentów polityki spójności, a więc Grecji, Irlandii, Hiszpanii czy Portugalii ${ }^{49}$.

${ }^{46}$ D. Jegorow, Falsyfikacja rozwoju społeczno-gospodarczego w skwantyfikowanym systemie sprawozdawczym w uktadzie regionalnym, w: J. Pach et al. (red.), Ekonomia umiaru. Realna perspektywa? Nowy paradygmat Grzegorza W. Kołodki, PWN, Warszawa 2016, s. 441.

${ }^{47}$ Public debt. How much is too much, 2015, economist.com/blogs/freecharge/2015/06/publicdebt [dostęp: 22.02.2017].

${ }^{48}$ G. Gorzelak, B. Jałowiecki, Koniunktura $w$ Polsce lokalnej 2013, „Studia Regionalne i Lokalne" 2014, nr 4(58), s. 18-19.

49 M. Słodowa-Hełpa, op. cit., s. 202. 
Oczywiście niniejsze opracowanie nie może aspirować do miana kompleksowej propozycji rozwiązania pojawiających się dylematów i wątpliwości. Autor ma jednak nadzieję, że tekst może stanowić inspirację dla licznych badaczy zagadnień związanych z finansami publicznymi. Szczegółowa analiza podjętych problemów przekracza bowiem ramy niniejszej publikacji. Niewątpliwie należy prowadzić dalsze badania. Niezmiernie interesujące mogą być analizy dotyczące zróżnicowania refinansowania zadłużenia czynione z różnych perspektyw - zarówno ze względu na poziom zamożności samorządów, jak też ze względu na położenie geograficzne. Uwarunkowania historyczne, nawet spuścizna rozbiorów, widoczne są bowiem do tej pory - m.in. w zakresie zamożności polskich samorządów, jak też ich potencjału rozwojowego ${ }^{50}$, a zbyt duże nierówności mogą poważnie osłabiać tendencje rozwojowe ${ }^{51}$.

\section{dr Daniel Jurewicz}

Regionalna Izba Obrachunkowa w Bydgoszczy

daniel.jurewicz@bydgoszcz.rio.gov.pl

\section{POLISH LOCAL GOVERNMENT DEBT REFINANCE}

\section{Sum mary}

The choice of the subject of this paper: the refinancing of the local government debt, was determined by the conviction that this field of research has not yet been sufficiently explored. Literature downplays this issue at the regional and local level. Thus the main aim of this work is the systematisation of information on the refinancing of public debt, including local government debt, and examination of the scale of this phenomenon existing throughout Polish municipalities. Debt indicators have been proposed to be added to the array of tools used for assessing the financial condition of local governments so that the objectives defined in the paper had both a theoretical as well as practical application. Problems and difficulties associated with the measurement of public debt have been identified, the concept of debt refinancing explained in more detail and a reference of a public debt to the local government debt has been made. Issues indicated in the article relate to debt restructuring and are sometimes confused with refinancing. The refinancing of Polish municipalities in the years 2003-2015 has been presented, followed by some proposals for measures applicable to the issues under discussion. The paper ends with a summary containing the main findings, and indicates issues that still require further research.

${ }^{50}$ G. Gorzelak, B. Jałowiecki, op. cit., s. 23-24.

${ }^{51}$ G.W. Kołodko, Społeczne i przestrzenne aspekty zróżnicowania dochodów we współczesnym świecie, „Nierówności Społeczne a Wzrost Gospodarczy” 2014, nr 39(3), s. 32. 